\title{
Analisis Kualitas Jaringan 2G Pada Frekuensi 900MHz Dan 1800MHz Di Area Purwokerto
}

\author{
Alfin Hikmaturokhman ${ }^{1}$, Wahyu Pamungkas ${ }^{2}$,Muhamad Alwi Sibro Malisi ${ }^{3}$ \\ Program Studi D3 Teknik Telekomunikasi Sekolah Tinggi Teknologi Telematika Telkom Purwokerto \\ alfin@st3telkom.ac.id ${ }^{1}$,wahyu@st3telkom.ac.id ${ }^{2}$, m.alwism@gmail.com ${ }^{3}$
}

\begin{abstract}
Abstrak - Teknologi 2G GSM masih banyak digunakan untuk komunikasi selular pada layanan suara maupun data. Performansi jaringan sangat berpengaruh terhadap layanan komunikasi yang digunakan. Drive test merupakan salah satu metode yang digunakan untuk mengamati performansi jaringan dari sisi penerima. Penelitian ini membahas tentang bagaimana cara pengamatan performasi jaringan dengan metode drive test single site. Parameter yang diamati untuk mengetahui performansi suatu jaringan 2G adalah Rx Level, Rx Qual, SQI dan Throughput. $\mathrm{Rx}$ Level yaitu digunakan untuk pengamatan level sinyal penerima dari BTS. Rx Qual digunakan untuk menentukan kualitas sinyal penerima. SQI merupakan nilai indikator dari kualitas layanan suara. Throughput menampilkan nilai pengamatan layanan data hasil download dan upload. Hasil pengamatan dari drive test single site ini memperoleh nilai level sinyal atau $R x$ Level $\geq \mathbf{- 8 5} \mathrm{dBm}$ dapat mencapai $80 \%$ untuk frekuensi $900 \mathrm{MHz}$ sedangkan pada frekuensi $1800 \mathrm{MHz}$ memperoleh 74,95\%, $\mathrm{Rx}$ Qual dari range 0-3 memperoleh 26,58\% pada frekuensi $900 \mathrm{MHz}$ dan $33,81 \%$ pada frekuensi 1800 MHz. Nilai throughput maksimum dapat mencapai target 60 Kbps pada penggunaan download GPRS dan 90 Kbps untuk penggunaan download EDGE, sedangkan nilai throughput upload dapat mencapai 30 Kbps pada GPRS dan 60 Kbps pada EDGE. Nilai maksimum throughput download maupun upload pada jaringan 2G di BTS Teluk masih dalam keadaan normal dengan melihat hasil nilai maksimum throughput berdasarkan Key Performance Indicator (KPI).
\end{abstract}

Keyword : Drive test, Rx Level, Rx Qual, SQI, Throughput, GPRS, EDGE

\section{PENDAHULUAN}

Teknologi telekomunikasi pada jaringan wireless pada saat ini berkembang dengan cepat. Teknologi telekomunikasi wireless merupakan teknologi yang memungkinkan untuk pengembangan dari teknologi wireline. Perkembangan teknologi wireless ini dapat dicontohkan dengan adanya jaringan seluler untuk komunikasi mobile.

Teknologi selular ini sangat berkembang dan Jaringan seluler yang baik harus mempunyai nilai kualitas standar dari parameter-parameter pengukuran. Sebuah jaringan akan dikatakan dalam kondisi baik jika hasil pengambilan data masih memenuhi standar kualitas dari kebijakan operator seluler. Teknik pengambilan data pada jaringan GSM salah satunya ialah dengan menggunakan metode drive test. Metode ini berguna untuk pengumpulan data parameter dari masing-masing kualitas layanan pada jaringan GSM baik $2 \mathrm{G}$ maupun $3 \mathrm{G}$ dengan menggunakan perangkat yang dapat digunakan untuk melakukan fungsi layanan pada jaringan GSM baik layanan suara maupun data dan dapat terhubung dengan software untuk pengumpulan data parameter pengujian. Hasil dari pengumpulan data ini dapat dianalisa untuk melihat kualitas layanan yang telah diuji.

Berdasarkan penggunaan layanan pada penggunaan layanan jaringan $2 \mathrm{G}$ itu maka dapat diukur kualitas pada jaringan 2G GSM pada penggunaan layanan suara dan data upload dan download, dan dari permasalahan tersebut maka penulis akan membuat judul penelitian dengan judul "Analisis Kualitas Jaringan 2G Pada Frekuensi 900MHz dan 1800MHz di Area Purwokerto". Penelitian ini akan membahas tentang bagaimana cara mengukur jaringan 2G GSM dengan frekuensi $900 \mathrm{MHz}$ dan $1800 \mathrm{MHz}$ dengan mengamati parameterparameter tertentu dengan metode drivetest. Perencanaan Penelitian ini akan membahas bagaimana melakukan analisis dari pengumpulan data menggunakan metode drivetest menggunakan TEMS Investigation 9.1 dan untuk menampilkan hasil pengujian kualitas jaringan GSM pada data hasil drivetest di frekuensi 900 dan $1800 \mathrm{MHz}$ pada BTS tertentu ditampilkan dengan menggunakan MapInfo 10.5 dan Nemo Analyze 6.10. Pengujian layanan yang akan dianalisa adalah suara dan data dengan menentukan parameter yang mengindikasikan kualitas layanan suara dan data. 


\section{I.1 PERUMUSAN MASALAH}

Perumusan masalah pada pembahasan penelitian ini adalah bagaimana hasil kualitas jaringan $2 \mathrm{G}$ pada frekuensi $900 \mathrm{MHz}$ dan $1800 \mathrm{MHz}$.

\section{I.2 TUJUAN DAN MANFAAT}

Tujuan dari penulisan penelitian ini adalah mengetahui kualitas jaringan $2 \mathrm{G}$ dengan frekuensi $900 \mathrm{MHz}$ dan $1800 \mathrm{MHz}$ dalam sebuah BTS dengan mengamati parameter $\mathrm{Rx}$ Level, coverage, $\mathrm{Rx}$ Qual, SQI dan throughput untuk layanan data pada masingmasing frekuensi.

Manfaat yang didapat dari penulisan penelitian ini adalah dapat digunakan sebagai bahan referensi praktikum drive test dalam mata kuliah teknik telekomunikasi dan mengetahui kualitas jaringan $2 \mathrm{G}$ pada frekuensi $900 \mathrm{MHz}$ dan $1800 \mathrm{MHz}$.

\section{I.3 METODOLOGI PENELITIAN}

- Metode penelitian

Metode penelitian adalah merupakan serangkaian kegiatan ilmiah dalam rangka pemecahan suatu permasalahan serta mencarikan penjelasan dan jawaban terhadap permasalahan serta memberikan alternatif bagi kemungkinan yang dapat digunakan untuk pemecahan masalah.

- Parameter yang diamati

Parameter yang diamati adalah nilai $\mathrm{Rx}$ Level, Rx Qual, coverage, SQI juga throughput untuk layanan data dari masingmasing panggilan di frekuensi $900 \mathrm{MHz}$ maupun $1800 \mathrm{MHz}$.

- Pengambilan Data

Pengumpulan data dilakukan menggunakan software TEMS Investigation 9.1 yang dihubungkan dengan handset yang mendukung layanan GSM. Pengambilan data drive test dilakukan dengan 3 metode yaitu:

a. Pengambilan data menggunakan metode drive test Single Site Verification (SSV) yaitu mengamati kinerja sebuah BTS dengan tiga buah sektor.

b. Mengambil data coverage dari sinyal GSM dengan masing-masing frekuensi yaitu 900 dan $1800 \mathrm{MHz}$ dengan melihat parameter BCCH, Rx Level, CI, Rx Qual, dan SQI.

c. Mengambil data throughput uploaddandownload layanan data ke ftp server sebesar $1 \mathrm{MB}$ sebanyak dua kali.

- Perangkat penelitian

Perangkat penelitian yang digunakan untuk pembuatan penelitian ini adalah menggunakan software TEMS Investigation 9.1 dan sebuah handset yang telah terinstall TEMS Pocket, perangkat tersebut berguna untuk merekam nilai-nilai dari parameter dalam pengukuran sinyal GSM. Pembuatan analisa dari nilai parameter yang telah ada digunakan software MapInfo dan Nemo Analyze agar menghasilkan sebuah gambaran keterangan hasil analisa.

\section{DASAR TEORI}

\subsection{Definisi Selular ${ }^{[1]}$}

Sistem selular memiliki cakupan area dengan sistem penggambaran heksagonal. Area inilah yang disebut dengan sel (cell). Penggunaan sisem heksagonal ini bertujuan agar semua daerah dapat tercakup tanpa adanya gap sel satu dengan yang lain.

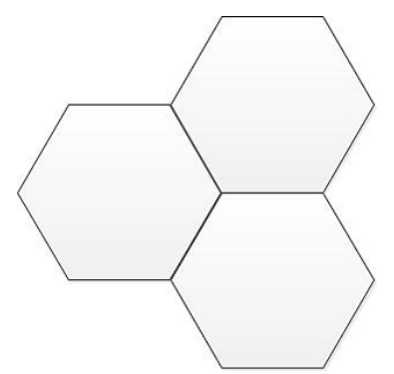

Gambar 1 Sistem Heksagonal pada selular ${ }^{[1]}$

Sebuah antena akan dapat mengirim dan menerima sinyal pada tiga daerah yang berbeda, di mana setiap sel hanya tercakup sebagian saja dari ketiga sel yang ter-cover. Ilustrasi penempatan antena pada sistem selular dapat dilihat pada gambar 2 .

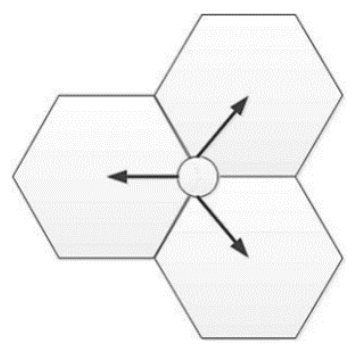

Gambar 2 Cakupan area sebuah antena ${ }^{[1]}$

\subsection{Frekuensi Reuse ${ }^{[1]}$}

Inti dari teknologi selular adalah konsep frekuensi reuse. Frekuensi reuse yaitu penggunaan frekuensi yang sama diatur untuk dapat digunakan kembali secara sistematis di seluruh area cakupan, terdapat beberapa frekuensi yang digunakan pada area yang luas dengan beberapa pengguna yang berkepentingan memakainya dalam channel yang sama. 


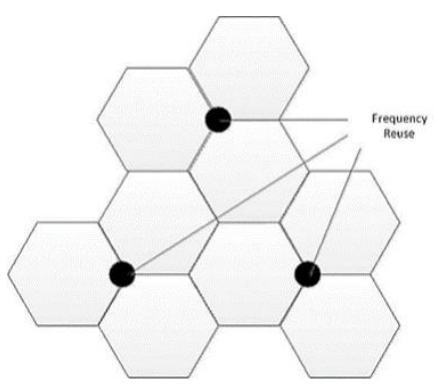

Gambar 3 FrequencyReuse ${ }^{[1]}$

Konsep frekuensi reuse dimana masing-masing huruf menyatakan kelompok frekuensi.

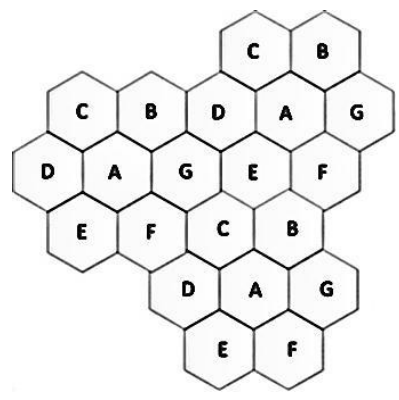

Gambar 4 Konsep FrequencyReuse ${ }^{[1]}$

\subsection{Arsitektur Jaringan GSM ${ }^{[2]}$}

Sebuah jaringan GSM dibangun dari beberapa komponen fungsional yang memiliki fungsi dan interface masing-masing yang spesifik. Jaringan GSM secara umum dapat dibagi menjadi tiga bagian utama yaitu Radio Sub System (RSS), Network and Switching Subsystem (NSS) dan Operation and Maintenance Subsystem (OMS).

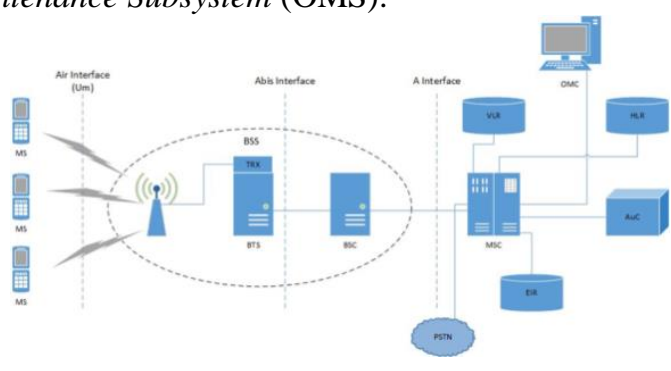

Gambar 5 Arsitektur jaringan GSM ${ }^{[2]}$

\section{Radio Sub System (RSS)}

Radio subsystem merupakan bagian dari struktur jaringan GSM yang terdiri dari:

a. Mobile Station (MS)

Mobile Station (MS) merupakan suatu perangkat yang berfungsi untuk menerima atau mengirimkan data. perangkat mobile seperti telepon seluler atau modem seluler.

- memberikan informasi mengenai user sehingga

b. Base Station Subsystem (BSS)
Base Station Subsystem (BSS) merupakan subsystem dari jaringan gsm yang secara langsung berhubungan dengan MS melalui air interface. BSS terdiri dari Base Transceiver System (BTS) dan Base Station Controller (BSC).

2. Network and Switching Subsystem (NSS)

Network and Switching Subsystem merupakan subsystem yang berfungsi sebagai interface antara jaringan GSM dengan jaringan luar lainnya. Terdapat lima komponen pokok dalam NSS yaitu Mobile Switching Center (MSC), Visitor Location Register (VLR), Home Location Register (HLR), Authentication Center (AuC) dan Equipment Identity Register (EIR).

3. Operation and maintenance subsystem (OMS) Bagian ini mengizinkan network provider untuk membentuk dan memelihara jaringan dari lokasi sentral.

\section{Metode Akses Jaringan GSM ${ }^{[2]}$}

Metode akses yang digunakan pada jaringan GSM untuk berkomunikasi dua arah secara downlink dan uplink(duplex transmission) menggunakan teknik Frequency Division Duplex (FDD). Teknik FDD ini berfungsi untuk membedakan transmisi uplink dan downlink.

Frequency Division Duplex (FDD) merupakan pentransmisian komunikasi secara uplink dan downlink menggunakan frekuensi yang berbeda. Jarak antara frekuensi uplink dan downlink disebut dengan duplexdistance.

Sedangkan multiple access yang digunakan pada sistem GSM adalah multiple access jenis Time Division Multiple Access (TDMA). Teknik ini digunakan untuk menghindari adanya interference saat melakukan kegiatan komunikasi yang dikarenakan adanya penempatan beberapa user dalam satu kanal frekuensi.

Pada TDMA, kanal frekuensi tidak secara permanen didedikasikan kepada mobile user secara individual, tetapi frekuensi tersebut digunakan secara bersama-sama dengan user lain hanya dengan waktu yang berbeda. Perbedaan waktu tersebut dibagi menjadi bagian-bagian yang dinamakan TDMA Time slot, yang kemudian akan diberikan secara individual kepada mobile user.

\section{E. Alokasi Frekuensi GSM}

Global System for Mobile communication (GSM) merupakan teknologi yang dapat mentransmisikan voice dan data, namun bit rate-nya masih kecil yaitu 9,6 kbps untuk data dan 13 kbps untuk voice, menggunakan teknologi circuit switch, artinya pembagian kanal di mana setiap satu kanal itu mutlak dimiliki oleh satu user. Sistem komunikasi bergerak seluler GSM mempunyai spesifikasi yang telah 
ditetapkan oleh ETSI seperti yang terlihat pada tabel 1. [3]

Tabel 1 Karakteristik GSM 900 ${ }^{[3]}$

\begin{tabular}{|c|c|}
\hline $\begin{array}{c}\text { Lebar pita } \\
\text { frekuensi }\end{array}$ & $\begin{array}{c}\text { Uplink } 890-915 \mathrm{MHz} \\
\text { Downlik } 935-960 \mathrm{MHz}\end{array}$ \\
\hline $\begin{array}{c}\text { Duplex } \\
\text { Spacing }\end{array}$ & $45 \mathrm{MHz}$ \\
\hline $\begin{array}{c}\text { Carrier } \\
\text { Spacing(ARFCN) }\end{array}$ & $200 \mathrm{KHz}$ \\
\hline $\begin{array}{c}\text { Kecepatan } \\
\text { Transmisi }\end{array}$ & $270 \mathrm{Kbps}$ \\
\hline Metode Akses & TDMA/FDD \\
\hline
\end{tabular}

Digital Celluler System (DCS) 1800 merupakan sistem turunan dari standar GSM yang dikembangkan oleh ETSI. DCS 1800 mempunyai bandwidth frekuensi sebesar $75 \mathrm{MHz}$ atau 374 carrier, sehingga kapasitas trafiknya tiga kali lebih tinggi dari jaringan seluler GSM 900. Pembagian kanalnya sama dengan frekuensi GSM $900 \mathrm{MHz}$ yaitu $200 \mathrm{KHz}$ sehingga jumlah carriernya (ARFCN) yaitu $75 \mathrm{MHz} / 0,2 \mathrm{MHz}$ menjadi 375 kanal. Penomoran kaal ARFCN-nya dimulai dari 511 dan berakhir 885. Perbedaan yang jelas nampak dari penggunaan range frekuensi sebagai kanal fisiknya. Karakteristik dari DCS 1800 dapat dilihat pada tabel 2.2. ${ }^{[3]}$

Tabel 2 Karakteristik DCS $1800^{[3]}$

\begin{tabular}{|c|c|}
\hline $\begin{array}{c}\text { Lebar pita } \\
\text { frekuensi }\end{array}$ & $\begin{array}{c}\text { Uplink } 1710-1785 \\
\mathrm{MHz} \\
\text { Downlink } 1805- \\
1880 \mathrm{MHz}\end{array}$ \\
\hline $\begin{array}{c}\text { Duplex } \\
\text { Spacing }\end{array}$ & $95 \mathrm{MHz}$ \\
\hline $\begin{array}{c}\text { Carrier } \\
\text { spacing (ARFCN) }\end{array}$ & $200 \mathrm{KHz}$ \\
\hline $\begin{array}{c}\text { Kecepatan } \\
\text { Transmisi }\end{array}$ & $270,83 \mathrm{Kbps}$ \\
\hline Metode Akses & TDMA/FDD \\
\hline
\end{tabular}

Teknologi GSM 1800 menyediakan layanan komunikasi bergerak dasar dengan kualitas yang lebih tinggi daripada GSM versi sebelumnya. Selain itu GSM 1800 mampu mengurangi panggilan gagal (drop calls) dan kegagalan koneksi akibat sibuknya jaringan. ${ }^{[4]}$

\subsection{Handover pada GSM ${ }^{[4]}$}

Handover adalah suatu cara atau pemindahan daerah pelayanan akibat pergerakan (mobilitas) pengguna. Pemindahan daerah layanan tersebut terjadi baik dalam satu BTS maupun antar BTS bahkan antar MSC, tanpa adanya pemutusan hubungan dan terjadi pemindahan frekuensi atau kanal secara otomatis yang dilakukan oleh sistem. Handover adalah proses perpindahan sel yang melayani suatu stasiun bergerak tertentu.

Proses mendapatkan sel yang ditunjuk sebagai sasaran handover maka MS dan BTS akan selalu melaporkan pengukurannya mengenai kualitas dan kekuatan sinyal pada arah downlink untuk MS dan arah uplink untuk BTS. Pengukuran dan pelaporannya dilakukan secara periodik dalam interval tertentu dan dikirim ke BSC dan MSC sebagai report. Selain karena kualitas dan kekuatan sinyal, handover dipengaruhi oleh jarak antara MS dan BTS dan juga dipengaruhi oleh Carrier to Interfrence Ratio $(\mathrm{C} / \mathrm{I}){ }^{[4]}$

\subsection{General Packet Radio Services (GPRS)}

GPRS merupakan teknologi yang disisipkan (overlay) diatas jaringan GSM untuk menangani komunikasi data pada jaringan. GPRS menggunakan teknik packet switch yaitu GPRS radio resource digunakan hanya jika user mengirimkan atau menerima data. Packet switch sebuah kanal digunakan secara bersama-sama selama kanal tersebut tidak kepenuhan dan kelebihan beban, sehingga pendudukan kanal pada packet switch lebih efisien. Secara teori GPRS mempunyai bit rate sampai dengan 171,2 Kbps. ${ }^{[3]}$

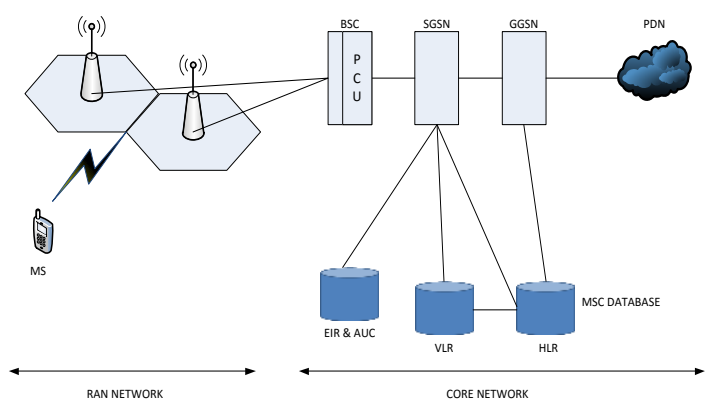

Gambar 6 Arsitektur Jaringan GPRS ${ }^{[3]}$

GGSN pada GPRS berfungsi sebagai Gateway antara jaringan GPRS dengan jaringan paket data standar (PDN). GGSN berperan sebagai antarmuka logic bagi PDN, dimana SGSN akan memancarkan dan menerima paket data dari SGSN atau PDN.

SGSN berfungsi sama seperti fungsi MSC pada jaringan GSM yang berfungsi sebagai Mobility Management, perhitungan trafik, secutity dan mengatur proses pengaksesan data. SGSN akan berhubungan dengan MSC/VLR dalam jaringan GSM. Hubungan tersebut digunakan untuk menyatukan interkoneksi antara GPRS dan GSM ketika resource yang sama sedanga digunakan oleh kedua teknologi tersebut.

PCU yang diletakan dalam BSC sebagai bagian dari Base Station Subsystem. PCU bertanggung jawab atas semua protokol radio GPRS dan komunikasi dengan SGSN.

Penggunaan handset yang support GPRS memungkinkan komunikasi data tetap berlangsung di jaringan GSM. Pengembangan teknologi GPRS di 
jaringan GSM dapat dilakukan secara efektif tanpa menghilangkan infrastruktur lama yaitu dengan penambahan beberapa hardware dan upgrade software baru pada terminal station GSM dan server GSM.

\subsection{Enhanced Data Rates for GSM Evolution (EDGE)} [5]

EDGE mempunyai arsitektur jaringan yang pada dasarnya sama dengan GPRS, baik antar mukanya, protokol dan prosedur aksesnya. Tujuan dari EDGE adalah menawarkan efisiensi lebar pita yang lebih tinggi lagi sehingga lebih banyak pengguna komunikasi data dapat ditangani pada pita selebar 200 $\mathrm{kHz}$.

Perubahan utama GSM untuk mendukung laju data yang tinggi yaitu dengan menggunakan modulasi 8PSK. Modulasi 8PSK membawa 3 bit per simbol sedangkan modulasi GMSK hanya satu bit per simbol. Kecepatan laju data dalam EGPRS/EDGE dapat ditingkatkan sampai tiga kali dengan menyesuaikan kanal fading fulctuation dan pemilihan coding scheme yang sesuai.

\subsection{Pengenalan TEMS ${ }^{[6]}$}

TEMS merupakan sebuah perangkat lunak yang digunakan untuk mengatur dan maintenance pada jaringan selular. Perangkat TEMS ini dikeluarkan oleh Ericsson yang digunakan untuk melakukan drive test. TEMS terdiri dari TEMS pocket pada ponsel dan dikendalikan oleh TEMS pada komputer. Salah satu fitur utama TEMS adalah menggunakan ponsel dengan bagian radio standar dan daya standar, yaitu suatu ponsel biasa dengan perangkat lunak yang dapat diubah. TEMS akan berperilaku seperti ponsel standar, namun memiliki fitur tambahan sebagai pengumpul informasi tentang level sinyal dan kualitas sinyal yang dipancarkan oleh BTS. Hasil output dari software TEMS ini yaitu berupa logfile

\subsection{Drive Test Menggunakan Test Mobile System $(\text { TEMS })^{[7]}$}

Drive Test ialah merupakan metode pengukuran sistem komunikasi bergerak pada sisi gelombang radio di udara yaitu dari arah BTS ke MS atau sebaliknya, dengan menggunakan ponsel yang didesain secara khusus untuk pengukuran. Drive Test bertujuan untuk mengambil dan mengukur kualitas sinyal serta dan dapat digunakan kembali untuk diamati kembali dan hasil pengamatan tersebut digunakan untuk memperbaiki segala masalah yang berhubungan dengan sinyal.

\subsection{Post Prosessing ${ }^{[7]}$}

Hasil dari pengumpulan data drive test dapat dianalisa untuk menentukan kualitas suatu jaringan yang telah diuji. Penentuan nilai kualitas jaringan tersebut dapat dilihat jika logfile di-plotting ke softwarepost prosessing lain misal MapInfo dan Nemo Analyze.

\section{PEMODELAN SISTEM}

\subsection{Waktu Dan Tempat Pengambilan Data}

Pengerjaan penelitian ini dilakukan pengambilan data dari kualitas sinyal yang meliputi jangkauan dan nilai level sinyal atau $\mathrm{Rx}$ Level, Rx Qual dan SQI pada saat panggilan suara serta nilai throughputupload dan download di BTS Teluk Purwokerto. Waktu pengambilan data dilakukan pada tanggal 2 September 2013 pada pukul 10.03 WIB sampai pukul 13.02 WIB. Pengambilan ini dilakukan pada siang hari yaitu pada jam sibuk bertujuan untuk mengetahui hasil performansi dari BTS tersebut dalam menangani layanan user yang padat. Operator yang diamati yaitu Telkomsel.

\subsection{Instrument Penelitian}

Peralatan yang dibutuhkan dalam pengambilan data dan juga analisa adalah :

1. Laptop Lenovo dengan sistem operasi Windows XP Service Pack 3

2. Software TEMS Investigation 9.1

3. Telepon selular Sony Ericsson K800i

4. USB Modem GSM Huawei E220

5. GPS

6. Software MapInfo Professional 10.5

7. Software Nemo Analyze 6.10

\subsection{Rancangan Tahap Penelitian}

Rancangan penelitian ini bersifat kajian teoritis berdasarkan hasil survei dan pengukuran langsung yang didukung dengan beberapa literatur yang berkaitan dengan teknik selular.

1. Survei

Survei dilakukan bertujuan untuk melakukan pengamatan di lapangan juga menentukan titik lokasi pengambilan data pada area purwokerto. Tahap ini adalah menentukan sebuah BTS yang akan diamati untuk pengambilan data. BTS yang ditentukan adalah BTS yang mempunyai transmisi frekuensi GSM $900 \mathrm{MHz}$ dan $1800 \mathrm{MHz}$.

Jalur drive test dimulai dari posisi BTS Teluk ke tiga arah jalan raya utama yaitu ke arah utara, barat dan timur. Arah utara dimulai dari titik BTS yaitu Jl. HOS Notosuwiryo hingga ke Jl. D.I. Pandjaitan sampai ke daerah Pasar Wage hingga sinyal dari BTS Teluk tidak dapat melayani MS. Arah Timur dimulai dari titik BTS hingga ke arah Sokaraja dengan melewati Jl Sultan Agung. Arah Barat dimulai kembali dari titik BTS berada hingga ke arah Jl. KH Agus Salim sampai ke Jl Gerilya. Gambar 3.1 merupakan penampakan jalur yang dilalui selama pengambilan data dengan drive test. Garis merah menandakan rute jalan yang dilalui. Semua jalur dilewati secara searah dari titik BTS ke tiga arah dan 
digunakan untuk pengambilan data pengamatan level dan kualitas sinyal.

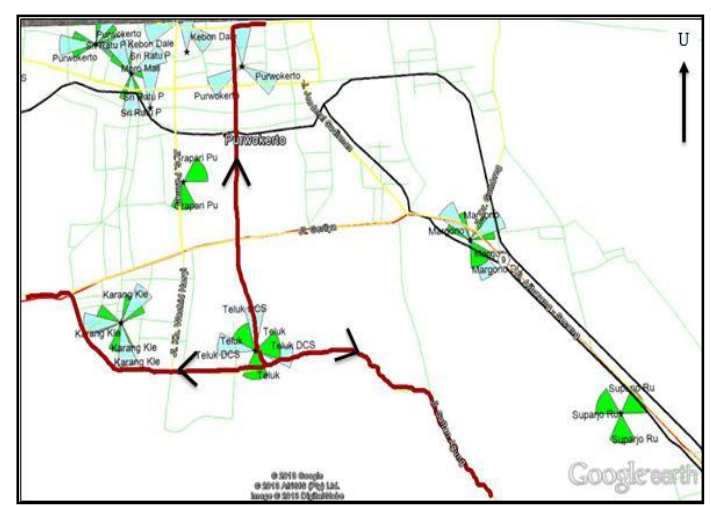

Gambar 7 Lokasi BTS yang diamati.

Pengambilan data throughput download dan upload menggunakan metode statis yaitu menetap di satu titik dengan perbedaan jarak dari BTS bervariasi dari masing-masing sektor. Gambar 8 merupakan titik-titik lokasi pengambilan data dari arah masing-masing sektor dengan ARFCN yang berbeda pada tiap titik, dimana pada gambar tersebut sektor berwarna hijau mentransmisikan frekuensi GSM 900 dan sektor dengan arsiran berwarna biru mentransmisikan frekuensi DCS 1800

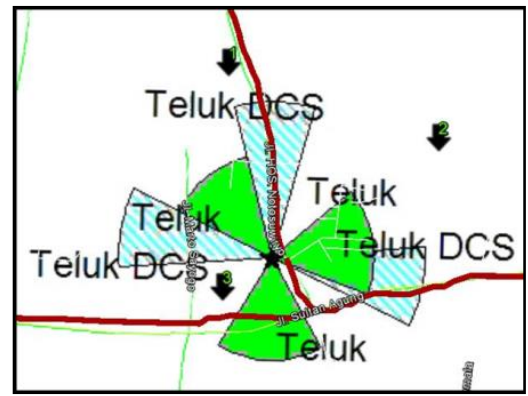

Gambar 8 Lokasi titik pegambilan throughput download dan upload.

\section{Pengambilan Data}

Tahap pengambilan data yaitu dengan metode drive test Single Site Verification (SSV) dengan mengamati kinerja sebuah BTS yang ada di area Purwokerto dengan menggunakan laptop yang bersistem operasi Windows XP SP3 dan ter-installsoftware TEMS Investigation 9.1, juga telah terpasang ponsel Sony Ericsson K800i serta GPS dan modem USB Huawei E220.

\subsection{Proses Pengamatan}

Pengamatan dilakukan di area purwokerto dengan memilih BTS Teluk yang mentransmisikan frekuensi GSM $900 \mathrm{MHz}$ dan $1800 \mathrm{MHz}$. Drive test digunakan untuk pengumpulan data parameter sinyal selular. Pengambilan data dilakukan secara mobile untuk mengamati nilai Rx Leveldengan idle modedan $\mathrm{Rx}$ Qualsecara dedicated modedi masing masing sektor sedangkan pangamatan nilai throughputupload dan download dilakukan secara statis.

\subsection{Post Processing}

Hasil dari post prosessing adalah sebuah plotting dari pengambilan data yang telah dilakukan. Masingmasing parameter yang telah di-plotting akan ditentukan dengan nilai standar yang telah ditentukan oleh operator.

Standar parameter dari nilai $\mathrm{Rx}$ level untuk menentukan level sinyal penerima dan jangkauan sinyal dapat dilihat pada tabel 3.

Tabel 3 Standar Parameter Rx Level

\begin{tabular}{|c|c|}
\hline \multicolumn{2}{|c|}{ Rx Level } \\
\hline Nilai & Warna \\
\hline$\geq-80$ & \\
\hline$<-80$ and $\geq-85$ & \\
\hline$<-85$ and $\geq-100$ & \\
\hline$<-100$ & \\
\hline
\end{tabular}

Hasil pengambilan data yang dapat diplotting dari hasil pengambilan data drive test selain $\mathrm{Rx}$ level yaitu parameter Rx qual untuk menentukan kualitas sinyal yang diterima. Nilai standar parameter dari Rx qual dapat dilihat pada tabel 4 .

Tabel 4 Standar Parameter Nilai Rx Qual

\begin{tabular}{|c|c|}
\hline \multicolumn{2}{|c|}{ Rx Qual } \\
\hline Nilai & Warna \\
\hline$\geq 5$ & \\
\hline$<5$ and $\geq 3$ & \\
\hline$<3$ and $\geq 1$ & \\
\hline$<1$ & \\
\hline
\end{tabular}

\subsection{Key Performance Indicator (KPI)}

Key Performance Indicator merupakan standar nilai yang harus dicapai dari hasil pengambilan data pada saat drive test sehingga dapat digunakan sebagai pedoman untuk menentukan kualitas jaringan apakah sesuai dengan yang diharapkan atau masih perlu dilakukan perbaikan kualitas jaringan. 
Tabel 5 Key Performance Indicators 2G GSM

\begin{tabular}{|l|l|r|}
\hline \multicolumn{2}{|c|}{ Standar Parameter } & Target \\
\hline \multirow{2}{*}{$\begin{array}{l}\text { Plotting Coverage } \\
\text { and Quality }\end{array}$} & $\begin{array}{l}\mathrm{Rx} \text { Level } \\
\mathrm{dBm}\end{array}$ & $80 \%$ \\
\cline { 2 - 3 } & $\mathrm{RxQual} \leq 3$ & -85 \\
\hline \multirow{2}{*}{$\begin{array}{l}\text { Max Throughput } \\
\text { GPRS }\end{array}$} & Download & $\begin{array}{r}30 \\
\mathrm{Kbps}\end{array}$ \\
\cline { 2 - 3 } & Upload & $\begin{array}{r}15 \\
\mathrm{Kbps}\end{array}$ \\
\hline \multirow{2}{*}{$\begin{array}{l}\text { Max Throughput } \\
\text { EGPRS }\end{array}$} & Download & $\begin{array}{r}90 \\
\mathrm{Kbps}\end{array}$ \\
\cline { 2 - 3 } & Upload & $\begin{array}{r}60 \\
\mathrm{Kbps}\end{array}$ \\
\hline
\end{tabular}

Persamaan yang digunakan untuk menghitung target dari nilai persentase KPI untuk plotting Rx level dan Rx Qual dapat dilihat pada tabel 3.4

Tabel 6 Persamaan Perhitungan KPI

\begin{tabular}{|c|c|}
\hline Parameter & Persamaan \\
\hline Rx Level & $\frac{\text { Sample } \geq-85}{\text { Total Sample }} \times 100 \%$ \\
\hline Rx Qual & $\frac{\text { Sample } \leq 3}{\text { Total Sample }} \times 100 \%$ \\
\hline
\end{tabular}

IV. HASIL DAN ANALISA

4.1 Pengamatan Level sinyal $900 \mathrm{MHz}$.

Hasil plotting pengamatan level sinyal pada frekuensi $900 \mathrm{MHz}$ denganpenguncian ARFCN 51, 56 dan 59 menggunakan MapInfo dapat dilihat pada gambar 9.

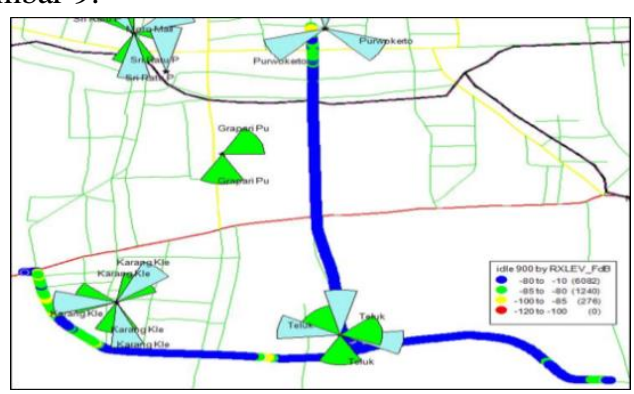

Gambar 9. Plotting MapInfo Rx Level pada frekuensi $900 \mathrm{MHz}$ ARFCN 51, 56 dan 59

Tabel7 HasilPengamatanIdle Mode Frekuensi 900MHz ARFCN 51, 56 dan 59.

\begin{tabular}{|c|c|c|}
\hline Nilai & $\begin{array}{c}\text { Sam } \\
\text { ple }\end{array}$ & $\begin{array}{c}\text { Percenta } \\
\text { ge }\end{array}$ \\
\hline-80 to -10 & 6082 & 80,05 \\
\hline-85 to -80 & 1240 & 16,32 \\
\hline
\end{tabular}

\begin{tabular}{|c|r|r|}
\hline-100 to -85 & 276 & 3,63 \\
\hline $\begin{array}{c}-120 \text { to }- \\
100\end{array}$ & 0 & 0 \\
\hline $\begin{array}{c}\text { TotalSamp } \\
\text { le }\end{array}$ & 7598 & 100 \\
\hline
\end{tabular}

Hasil perhitungan Rx Level dapat digunakan untuk menentukan nilai KPI yang telah ditentukan pada tabel 7 . Sehingga nilai KPI dengan nilai Rx Level $\geq-85$ adalah $16,32 \%+80,04 \%=96,36 \%$. Hasil ini tentunya sudah memenuhi target yang telah ditentukan oleh operator dan dapat dikatakan level sinyal pada frekuensi $900 \mathrm{MHz}$ ini masih dikategorikan baik.

Tabel 8 Hasil Pengamatan Nilai Rx Level 900 MHz ARFCN 51, 56 dan 59.

\begin{tabular}{|l|l|}
\hline & Nilai $(\mathrm{dBm})$ \\
\hline Rata-rata & $-71,252$ \\
\hline Maksimum & -54 \\
\hline Minimum & -88 \\
\hline JumlahSampel & 1164311,76 \\
\hline
\end{tabular}

\subsection{Level Sinyal Frekuensi $1800 \mathrm{MHz}$}

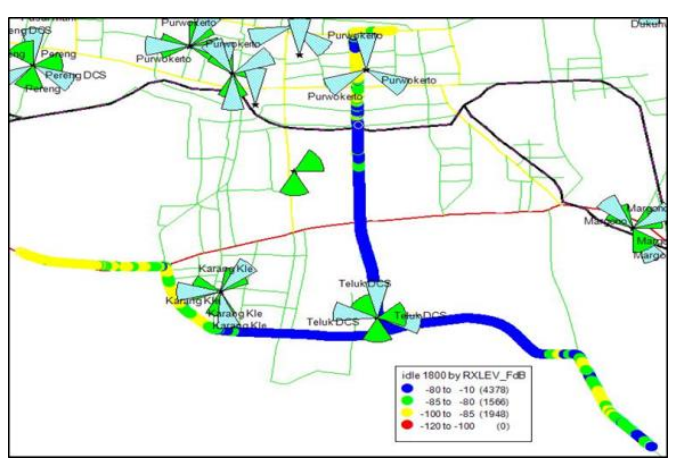

Gambar 10 Plotting MapInfo Rx Level Frekuensi $1800 \mathrm{MHz}$ ARFCN 830, 705 dan 610.

Tabel 9 Hasil Pengamatan Idle Mode Frekuensi $1800 \mathrm{MHz}$ ARFCN 830, 705 dan 610.

\begin{tabular}{|c|r|r|}
\hline Nilai & Sample & \multicolumn{1}{c|}{ Percentage } \\
\hline-80 to -10 & 4378 & 55,47 \\
\hline-85 to -80 & 1566 & 19,84 \\
\hline $\begin{array}{c}-100 \text { to }- \\
85\end{array}$ & 1948 & 24,68 \\
\hline $\begin{array}{c}-120 \text { to }- \\
100\end{array}$ & 0 & 0 \\
\hline Total Sample & 7892 & 100 \\
\hline
\end{tabular}

Hasil perhitungan Rx Level dapat digunakan untuk menentukan nilai KPI yang telah ditentukan pada 
tabel 9 . Sehingga nilai KPI dengan nilai $\mathrm{Rx}$ Level $\geq$ 85 adalah $19,84 \%+55,47 \%=74,95 \%$. Hasil ini tentunya belum memenuhi target yang telah ditentukan oleh operator dan dapat dikatakan level sinyal pada frekuensi $900 \mathrm{MHz}$ ini masih dikategorikan sedang dan masih masuk dalam batas wajar. Hal ini dapat dikarenakan jangkauan yang terlalu jauh tetapi daya yang dipancarkan semakin melemah.

Tabel 10 Hasil Pengamatan Nilai Rx Level $1800 \mathrm{MHz}$ ARFCN 830, 705 dan 610.

\begin{tabular}{|l|c|}
\hline & $\begin{array}{c}\text { Nilai } \\
(\mathrm{dBm})\end{array}$ \\
\hline Rata-rata & $-71,252$ \\
\hline Maksimum & -54 \\
\hline Minimum & -88 \\
\hline Jumlah Sampel & 1164311,76 \\
\hline
\end{tabular}

4.3 Kualitas Sinyal Frekuensi $900 \mathrm{MHz}$.

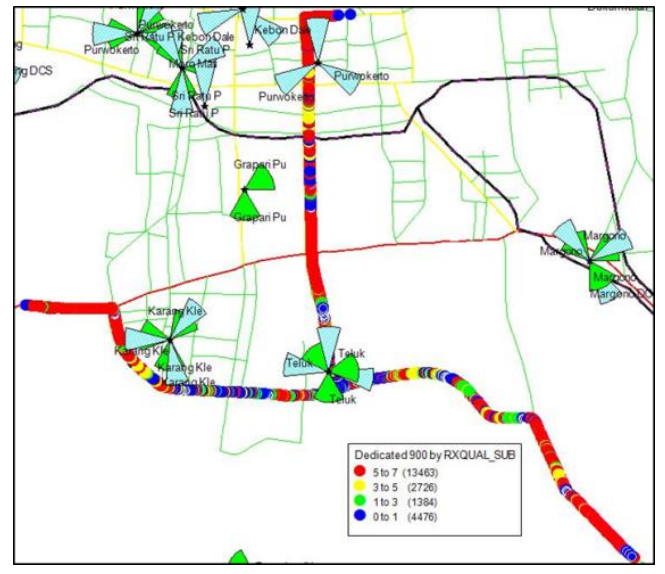

Gambar 11Plotting MapInfo Rx Qual Frekuensi $900 \mathrm{MHz}$ ARFCN 51, 56 dan 59.

Tabel 11 Hasil Pengamatan Dedicated Mode Frekuensi 900MHz ARFCN 51, 56 dan 59

\begin{tabular}{|c|c|c|c|}
\hline $\begin{array}{c}\text { RxQual } \\
\text { Distribution }\end{array}$ & Sample & Percentage & Result \\
\hline RxQual $0-1$ & 4476 & 20,30 & \\
\hline RxQual $1-3$ & 1384 & 6,28 & \\
\hline RxQual $3-5$ & 2726 & 12,36 & \\
\hline RxQual 5 - 7 & 13463 & 61,06 & \\
\hline TotalSample & 22049 & 100 & \\
\hline $\begin{array}{l}\text { Sample RxQual } \\
0-3\end{array}$ & & & $26,58 \%$ \\
\hline
\end{tabular}

4.4 Kualitas sinyal pada frekuensi $1800 \mathrm{MHz}$.

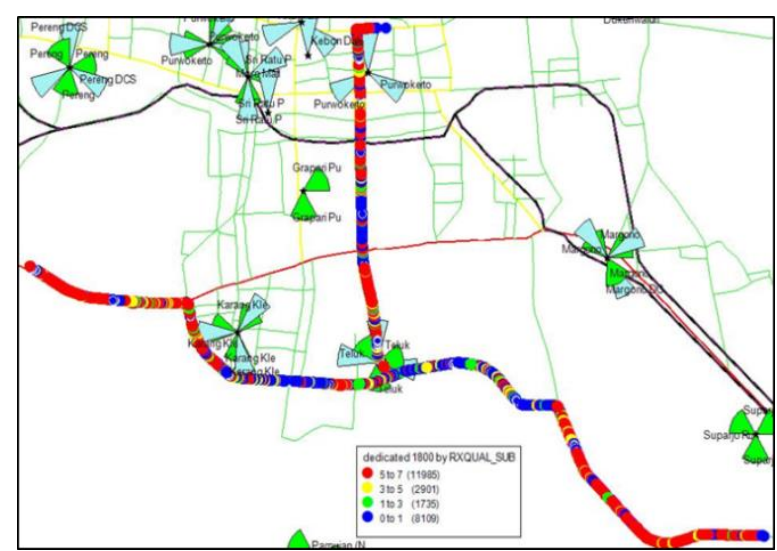

Gambar 12. Plotting MapInfo Rx Qual Pada Frekuensi 1800 MHz ARFCN 830, 705 dan 610.

Tabel 12. Hasil Pengamatan Dedicated Mode Frekuensi 1800 MHz ARFCN 830, 705 dan 610.

\begin{tabular}{|c|c|c|c|}
\hline $\begin{array}{c}\text { RxQual } \\
\text { Distribution }\end{array}$ & Sample & Percentage & Result \\
\hline RxQual $0-1$ & 8109 & 32,79 & \\
\hline RxQual $1-3$ & 1735 & 7,02 & \\
\hline RxQual 3-5 & 2901 & 11,73 & \\
\hline RxQual 5-7 & 11985 & 48,46 & \\
\hline TotalSample & 24730 & 100 & \\
\hline $\begin{array}{l}\text { Sample } \mathrm{RxQual} \\
0-3\end{array}$ & & & $33,81 \%$ \\
\hline
\end{tabular}

4.5 Pengamatan Throughput Layanan Data Download GPRS 900 MHz.

Hasil tabel 13 berdasarkan hasil post prosessing logfile dengan Nemo Analyze.

Tabel 13 Hasil Pengamatan Throughput Download dan Upload GPRS $900 \mathrm{MHz}$.

\begin{tabular}{|c|c|c|}
\hline \multirow{2}{*}{$\begin{array}{c}\text { ARF } \\
\text { CN }\end{array}$} & \multicolumn{2}{|c|}{ Maksimum Throughput } \\
\cline { 2 - 3 } & $\begin{array}{c}\text { Download } \\
\text { (bps) }\end{array}$ & $\begin{array}{c}\text { Upload } \\
\text { (bps) }\end{array}$ \\
\hline 51 & 86920 & 42824 \\
\hline 56 & 81408 & 42400 \\
\hline 59 & 83528 & 42400 \\
\hline
\end{tabular}

4.6 Throughput Download dan Upload GPRS 1800 $\mathrm{MHz}$.

Proses Pengambilan data pada frekuensi 1800 $\mathrm{MHz}$ sama dengan pada frekuensi $900 \mathrm{MHz}$ hanya ARFCN yang digunakan berbeda yaitu nilai yang digunakan adalah 830, 705, dan 610 . 
Tabel 14 Hasil Pengamatan ThroughputDownload dan Upload GPRS $1800 \mathrm{MHz}$.

\begin{tabular}{|r|c|c|}
\hline \multirow{2}{*}{ ARFCN } & \multicolumn{2}{|c|}{ Maksimum Throughput } \\
\cline { 2 - 3 } & $\begin{array}{c}\text { Download } \\
\text { (bps) }\end{array}$ & $\begin{array}{c}\text { Upload } \\
\text { (bps) }\end{array}$ \\
\hline 830 & 88616 & 41976 \\
\hline 705 & 72928 & 41976 \\
\hline 610 & 37744 & 39432 \\
\hline
\end{tabular}

4.7 PlottingDownload dan Upload EDGE $1800 \mathrm{MHz}$.

Tabel 15 Hasil Pengamatan ThroughputDownload dan Upload EDGE $1800 \mathrm{MHz}$.

\begin{tabular}{|c|c|c|}
\hline \multirow{2}{*}{ ARFCN } & \multicolumn{2}{|c|}{ Maksimum Throughput } \\
\cline { 2 - 3 } & $\begin{array}{c}\text { Download } \\
\text { (bps) }\end{array}$ & $\begin{array}{c}\text { Upload } \\
\text { (bps) }\end{array}$ \\
\hline 830 & 185600 & 113338 \\
\hline 705 & 200887 & 106968 \\
\hline 610 & 139026 & 115232 \\
\hline
\end{tabular}

\section{KESIMPULAN DAN SARAN}

\subsection{Kesimpulan}

a. Pengukuran jaringan $2 \mathrm{G}$ pada GSM dan DCS dapat dilakukan dengan menggunakan metode drive test dengan mengamati Rx Level, Rx Qual, SQI juga Throughputdownload dan upload.

b. Hasil level sinyal pada penggunaan parameter Rx Level frekuensi $900 \mathrm{MHz}$ dengan posisi MS idle mode sudah mencapai target $80 \%$ pada range nilai $\mathrm{Rx}$ Level $\geq-85 \mathrm{dBm}$ yaitu sebesar $96,36 \%$.

c. Level sinyal pada range nilai $\mathrm{Rx}$ Level $\geq$ $85 \mathrm{dBm}$ frekuensi $1800 \mathrm{MHz}$ dengan posisi MS idle mode yaitu sebesar 74,95\% hasil ini belum mencapai target berdasar KPI yaitu sebesar $80 \%$.

d. Nilai sampel Rx Qual dari range nilai 0-3 pada penggunaan dedicated mode pada frekuensi $900 \mathrm{MHz}$ mendapatkan nilai sebesar $26,58 \%$.

e. Nilai sampel Rx Qual dari range nilai 0-3 pada dedicated mode di frekuensi 1800 $\mathrm{MHz}$ mendapat nilai sampel sebesar $33,81 \%$.

f. Hasil sampel Rx Qual pada kedua pengujian frekuensi belum memenuhi target KPI yaitu sebesar $80 \%$, dikarenakan MS dalam keadaan terkunci ke satu BTS sehingga tidak dapat melakukan handover ke BTS terdekat pada saat level daya yang diterima MS sudah menurun.

g. Nilai maksimum throughput download maupun upload pada jaringan $2 \mathrm{G}$ di BTS Teluk masih dalam keadaan normal dengan melihat hasil nilai maksimum throughput berdasarkan Key Performance Indicator (KPI).

5.2 Saran

a. Waktu pengambilan data dapat ditambah durasinya dan berbeda kondisi trafik.

b. Pembahasan masalah jaringan GSM dapat diperluas hingga ke optimasi jaringan.

\section{REFERENSI}

[1] Edi S. Mulyanta, Kupas Tuntas Telepon Selular Anda. Yogyakarta, Indonesia: ANDI, 2005.

[2] Riana Puspita Dewi, "Analisis Optimalisasi Kapasitas Trafik Dengan Multiband Cell (MBC) Pada Jaringan GSM Di PT. XL AXIATA, Tbk Purwokerto," Akademi Teknik Telekomunikasi Sandhy Putra Purwokerto, Purwokerto, 2011.

[3] Gunawan Wibisono, Uke Kurniwan Usman, and Gunadi Dwi Hantoro, Konsep Teknologi Seluler. Bandung: Informatika Bandung, 2008.

[4] Tri Devi Septyani, "Analisis Proses Pindah Tangan (Handover) Ditinjau Dari Level Daya Sinyal Terima Studi Kasus Pada PT. Telkomsel Grapar Purwokerto," Akademi Teknik Telekomunikas Sandhy Putra Purwokerto, Purwokerto, 2007.

[5] Luthfiana, "Analisa Penerapan Teknologi UMTS Untuk Mengatasi Permasalahan Kapasitas Pada Jaringan 3G (GSM) Studi Kasus Di PT. Indosat Tbk. Purwokerto," Akademi Teknik Telekomunikasi Sandhy Putra Purwokerto, Purwokerto, 2012.

[6] Dedy Kurniawan Sukarno, "Analisis Proses Pindah Tangan (Handover) Ditinjau Dari Parameter Kualitas Sinyal Pada Frekuensi Dan Daerah Kerja Jaringan Sistem Seluler GSM PT.Exelcomindo," Akademi Teknik Telekomunikasi Sandhy Putra Purwokerto, Purwokerto, 2006.

Nur Akhmadi, "Analisis Kualitas Jaringan High Speed Downlink Packet Access (HSDPA) Dengan Metode Drive Test Indoor Di Area Surabaya," Sekolah Tinggi Teknologi Telematika Telkom, Purwokerto, 2013. 